\title{
Pengaruh Jenis Larutan Pemasak Terhadap Kualitas Pulp Daun Pisang
}

\author{
Noer Kurnia Dewi, Risnita Vicky Listyarini*
}

Pendidikan Kimia, Universitas Sanata Dharma, Yogyakarta, 55281, Indonesia

\begin{tabular}{l} 
I N F O A R T I K E L \\
\hline Diterima 05 Maret 21 \\
Disetujui 29 April 21 \\
\\
\hline Keywords: \\
pulp making; banana leaves; \\
solvents \\
\\
\hline Kata kunci: \\
pembuatan pulp; daun pisang; \\
larutan pemasak
\end{tabular}

*e-mail: risnita.vicky@usd.ac.id

\begin{abstract}
A B STR A C T
The need for paper continues to increase, indicating that there is an alternative wood material that can be used as a base for making pulp. Materials that can be used are dried banana leaves which contain cellulose. The quality of the pulp can be obtained by the characteristics of the pulp produced. This study was conducted to determine the effect of the type of solvents on the pulp quality of banana leaves. The pulp has been made using delignification process with addition of $3 \% \mathrm{NaOH}$ or $3 \% \mathrm{Na}_{2} \mathrm{CO}_{3}$ $3 \%$ and heating up to 120 minutes, at $105{ }^{\circ} \mathrm{C}$. Pulp quality was obtained from the results of pulp analysis, cellulose content, water content, physical appearances and qualitative analysis by FTIR. From the analysis of cellulose content, water content and FTIR instruments, pulp made with 3\% $\mathrm{NaOH}$ solution are better suited to $3 \%$ $\mathrm{Na} 2 \mathrm{CO} 3$ where the resulting pulp has a water content of $4.96 \%$, a smooth and fibrous texture, a rich color, and produces a cellulose hydroxyl absorption band that is stronger than the pulp made of $3 \% \mathrm{Na}_{2} \mathrm{CO}_{3}$. However, the pulp made from $3 \% \mathrm{NaOH}$ solution has a lower yield (56.5\%) and cellulose content (26.07\%) than $\mathrm{Na}_{2} \mathrm{CO}_{3} 3 \%$. Dried banana leaves can be used as an alternative in pulp making.
\end{abstract}

\section{A B STRAK}

Kebutuhan kertas terus meningkat yang menunjukkan perlu adanya adanya bahan alternatif pengganti kayu yang dapat dijadikan sebagai bahan dasar pembuatan pulp. Bahan yang dapat digunakan adalah daun pisang kering yang memiliki kandungan selulosa Kualitas pulp dipengaruhi oleh kerakteristik dari pulp yang dihasilkan. Penelitian ini dilakukan untuk mengetahui pengaruh jenis larutan pemasak terhadap kualitas pulp dari daun pisang. Pulp dibuat melalui proses delignifikasi menggunakan larutan pemasak $\mathrm{NaOH} 3 \%$ dan $\mathrm{Na}_{2} \mathrm{CO}_{3} 3 \%$ selama 120 menit, pada suhu $105^{\circ} \mathrm{C}$. Kualitas pulp ditinjau dari analisis rendemen pulp, kadar selulosa, kadar air, bentuk fisik dan analisis kualitatif dengan FTIR. Dari analisis kadar selulosa, kadar air dan instrumen FTIR, pulp yang dibuat dengan larutan pemasak $\mathrm{NaOH} 3 \%$ lebih baik daripada $\mathrm{Na}_{2} \mathrm{CO}_{3} 3 \%$ di mana pulp yang dihasilkan memiliki kadar air yang 4,96\%, tekstur yang halus dan berserat, warna yang lebih terang, dan menghasilkan pita serapan hidroksil selulosa yang lebih kuat dibandingkan pulp yang dibuat dari $\mathrm{Na}_{2} \mathrm{CO}_{3} 3 \%$. Namun, pulp yang dibuat dari larutan $\mathrm{NaOH} 3 \%$ memiliki rendemen (56,5\%) dan kadar selulosa $(26,07 \%)$ yang lebih rendah dibandingkan $\mathrm{Na}_{2} \mathrm{CO}_{3} 3 \%$. Daun pisang kering dapat dijadikan sebagai alternatif dalam pembuatan pulp.

\section{Pendahuluan}

Kertas merupakan salah satu bahan yang masih dibutuhkan oleh masyarakat. Semua sektor baik pemerintah, pengusaha, dan dunia pendidikan membutuhkan kertas untuk administrasi, media menyampaikan informasi dan sebagainya. Menurut data dari Kemenperin
RI, konsumsi kertas di dunia telah mencapai 394 juta ton pada tahun 2016 dan akan terus meningkat menjadi 490 juta ton pada 2020 [1]. Industri kertas di Indonesia memproduksi kertas dari kayu pohon. Kebutuhan akan kertas yang terus meningkat berbanding lurus dengan jumlah pohon yang harus ditebang untuk 
memenuhi perminataan. Adanya usaha reboisasi tidak akan cukup untuk menanggulangi penebangan pohon yang terus meningkat. Menipisnya pohon di hutan berdampak buruk terhadap iklim di Indonesia. Bahan alternatif pengganti kayu untuk bahan pembuatan kertas perlu diteliti dari tumbuhan di Indonesia.

Kertas dibuat dari bubur kertas ( $p u l p$ ) yang mengandung selulosa. Bubur kertas (pulp) merupakan bahan utama dalam pembuatan kertas yang mengandung sebagian besar selulosa. Selulosa dapat ditemukan di sebagian besar tumbuhan [2]. Selulosa adalah komponen yang terdapat pada tumbuhan dengan bobot molekul mencapai 50.000-500.000 dan terdapat di dalam dinding sel tanaman seperti dalam jerami, kapas, kertas, dan berbagai macam kayu $[3,4]$. Selulosa memiliki rumus kimia $\left(\mathrm{C}_{6} \mathrm{H}_{10} \mathrm{O}_{5}\right)_{\mathrm{n}}$ yang merupakan polimer yang tersusun dari monomer berupa $\beta$-D-glukopiranosa.

Hampir sebagian besar tanaman di Indonesia mengandung selulosa yang berpotensi untuk dijadikan sebagai bubur kertas (pulp) [4]. Indonesia merupakan negara tropis agraris dengan hasil perkebunan bervariasi salah satunya adalah pohon pisang. Bagian pohon pisang yang kurang dimanfaatkan adalah daun pisang yang sudah kering. Daun pisang kering oleh masyarakat hanya dibuang dan dibakar sehingga dapat menambah polusi udara. Bagian pohon pisang yang digunakan pada penelitian ini adalah daun pisang. Daun pisang mengandung serat berupa $26 \%$ selulosa, $17 \%$ hemiselulosa, dan $25 \%$ lignin [5]. Lebih lanjut, penelitian lain mengemukakan bahwa kandungan selulosa dan lignin dalam daun pisang berturut-turut sebesar $44-54 \%$ dan $11-22 \%$ [6]. Pemanfaatan daun pisang kering sebagai bahan baku pembuatan pulp ini dapat dijadikan sebagai usaha untuk meningkatkan nilai ekonomi hasil perkebunan. Dimana, daun pisang kering yang awalnya hanya dibuang dapat dijual atau dimanfaatkan untuk pembuatan pulp atau bubur kertas.

Sebagian besar tanaman memiliki komponen lignoselulosa yang terdiri dari selulosa, hemiselulosa, dan lignin. Limbah tanaman mengandung $40-60 \%$ selulosa, 20 $30 \%$ hemiselulosa, dan $15-30 \%$ lignin [7].
Komponen utama yang diperlukan untuk membuat kertas adalah selulosa sehingga komponen lain seperti hemiselulosa dan lignin perlu dihilangkan melalui proses delignifikasi. Dalam pembuatan pulp, dapat dilakukan melalui proses kimia yang meliputi proses soda, proses sulfat, dan proses sulfit [8]. Bahan yang sering digunakan untuk proses sulfat adalah $\mathrm{Na}_{2} \mathrm{~S}, \mathrm{Na}_{2} \mathrm{CO}_{3}$, dan $\mathrm{Na}_{2} \mathrm{SO}_{4}$. Berbeda dengan proses soda yang menggunakan larutan alkali seperti $\mathrm{NaOH}$ sedangkan proses sulfit menggunakan garam sulfit [8]. Sebagian besar penelitian terhadap pulp, menggunakan $\mathrm{NaOH}$ sebagai larutan pemasaknya. Setiap proses kimia yang berbeda dimungkinkan berpengaruh terhadap kualitas pulp yang dihasilkan.

Pembuatan pulp yang memanfaatkan biomassa berupa tumbuhan ini sudah banyak dilakukan seperti penelitian yang dilakukan oleh [9] yang membuat pulp dari ampas tebu melalui proses soda. Pembuatan pulp dari batang pisang dan mengkaji pengaruh konsentrasi $\mathrm{NaOH}$ dan waktu pemasakan terhadap kulitas pulp telah dilakukan oleh [7]. Berdasarkan penelitian tersebut konsentrasi $\mathrm{NaOH}$ paling optimum sebesar $2 \%$ dengan waktu pemasakan selama 120 menit dapat menghasilkan pulp dengan kualitas paling baik. Penelitian lain dilakukan oleh [10] yang mengkaji faktor-faktor yang mempengaruhi proses pembuatan pulp dimana suhu optimum untuk menghasilkan kadar selulosa tertinggi pada suhu $95{ }^{\circ} \mathrm{C}$; dengan waktu pemasakan selama 60-120 menit, konsentrasi etanol sebesar $40 \%$, dan perbandingan larutan pemasak sebesar 8:1. Setiap proses kimia dengan jenis larutan pemasak yang berbeda memiliki kelebihan dan kekurangannya masing-masing sehingga dapat mempengaruhi kualitas pulp. Kualitas pulp dipengaruhi oleh kerakteristik dari pulp yang dihasilkan. Faktor yang mempengaruhi mutu pulp diantaranya adalah panjang serat, kadar selulosa, kadar abu, kadar lignin, dan bilangan kappa [8]. Penelitian ini bertujuan untuk mengetahui pengaruh jenis larutan pemasak terhadap kualitas pulp dari daun pisang yang ditinjau dari rendemen pulp, kadar selulosa, kadar air, dan bentuk fisiknya. 


\section{Bahan dan Metode}

Peralatan yang digunakan dalam penelitian ini adalah erlenmeyer, labu ukur, gelas kimia, gelas ukur, pengaduk gelas, penyaring, pipet tetes, cawan petri oven, hot plate, magnetic stirer, autoklaf, desikator, neraca, dan alat instrumentasi FTIR.

Bahan-bahan yang digunakan dalam penelitian ini adalah daun pisang, $\mathrm{NaOH} 3 \%$, Etanol $40 \%, \mathrm{Na}_{2} \mathrm{CO}_{3} 3 \%$, akuades, asam asetat $2 \mathrm{~N}$, asam sulfat, dan kertas saring, indikator universal.

\section{Tahapan Persiapan}

Daun pisang dibersihkan dari pengotor. Daun pisang dijemur di bawah sinar matahari sampai kering. Daun pisang kering disimpan dalam tempat yang tertutup. Daun pisang dipotong dengan ukuran yang sama. Daun pisang kering tersebut dianalisis kadar air, kadar selulosa. Kandungan selulosa dan lignin juga dianalisis menggunakan FTIR. Daun pisang dikeringkan di dalam oven selama 1 jam kemudian didinginkan dalam desikator.

\section{Tahapan Pembuatan Pulp dari Daun Pisang}

Beberapa tahapan dari pembuatan pulp diadaptasi dan dimodifikasi dari penelitian [7]. 10 gram daun pisang dimasukkan dalam tiga gelas kimia. Larutan pemasak berupa $\mathrm{NaOH}$ $3 \%$ dan $\mathrm{Na}_{2} \mathrm{CO}_{3} 3 \%$ dimasukkan pada masingmasing gelas kimia dengan perbandingan 8:1 terhadap berat daun pisang. Ketiga gelas kimia dimasukkan dalam autoklaf. Autoklaf dioperasikan pada suhu $105{ }^{\circ} \mathrm{C}$ selama 120 menit. Daun pisang yang sudah dimasak kemudian dikeluarkan dari autoklaf dan didinginkan hingga mencapai suhu kamar. Residu dan filtrat dipisahkan dengan menggunakan kertas saring. Residu yang didapatkan kemudian dicuci dengan etanol $40 \%$ dan dilanjutkan pencucian dengan air panas lalu dikeringkan dalam oven pada suhu $105{ }^{\circ} \mathrm{C}$ selama 60 menit. Padatan yang telah kering ditimbang (sebagai berat pulp kering). Analisis yang dilakukan adalah pengukuran rendemen pulp, kadar selulosa dan kadar air. Analisis kandungan selulosa dan lignin dilakukan dengan FTIR.
Analisis Kadar Selulosa (Metode SNI 14-04441989)

Tiga gram pulp kering ditimbang. Pulp

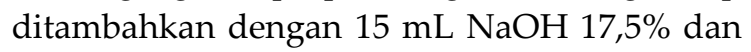
diaduk selama 1 menit. $10 \mathrm{~mL} \mathrm{NaOH} \mathrm{17,5 \%}$ ditambahkan dan diaduk selama 45 detik. Sebanyak $10 \mathrm{~mL} \mathrm{NaOH} \mathrm{17,5 \%} \mathrm{ditambahkan} \mathrm{lagi}$ dan diaduk selama 15 detik. Campuran dibiarkan selama 3 menit dan ditambahkan 10 $\mathrm{mL} \mathrm{NaOH} \mathrm{17,5 \%} \mathrm{dengan} \mathrm{pengadukan} \mathrm{selama}$ 10 menit. Penambahan selanjutnya adalah larutan $\mathrm{NaOH} 17,5 \%$ sebanyak $10 \mathrm{~mL}$ setelah 2,$5 ; 5 ; 7,5$ menit. Campuran dibiarkan selama 30 menit dalam keadaan tertutup. Setelah 30 menit, campuran ditambahkan $100 \mathrm{~mL}$ akuades. Campuran dan dipisahkan dari endapannya. Endapan yang didapatkan kemudian dicuci dengan $50 \mathrm{~mL}$ akuades sebanyak 5 kali. Endapan yang telah dicuci kemudian ditambahkan dengan 12,5 $\mathrm{mL}$ asam asetat $2 \mathrm{~N}$ dan diaduk selama 5 menit. Campuran kemudian dicuci dengan akuades hingga bebas asam (diuji dengan kertas lakmus). Endapan dikeringkan dalam oven pada suhu $105{ }^{\circ} \mathrm{C}$ selama 60 menit dan dimasukkan dalam desikator. Endapan ditimbang hingga diperoleh berat yang konstan. Kadar selulosa dihitung dengan rumus persamaan 1 [7].

$$
\begin{aligned}
& \text { Kadar selulosa }= \\
& \frac{\text { Berat endapan selulosa }}{\text { Berat pulp }} \times 100 \%
\end{aligned}
$$

\section{Analisis kadar air}

Cawan dipanaskan pada suhu $105{ }^{\circ} \mathrm{C}$ selama 1 jam dan didinginkan dalam desikator. 5 gram sampel ditimbang. Sampel dipanaskan di dalam oven pada suhu $105{ }^{\circ} \mathrm{C}$ selama 1 jam. Sampel kemudian didinginkan di dalam desikator dan ditimbang [10]. Kadar air dihitung dengan persamaan 2 .

Kadar Air $=$

$\frac{\text { berat sampel awal-berat sampel dioven }}{\text { berat sampel awal }} \times 100 \%$

\section{Analisis dengan FTIR}

Produk pulp kering dianalisis menggunakan FTIR pada bilangan gelombang $500-4000 \mathrm{~cm}^{-1}$ untuk uji kualitatif kandungan 
selulosa dan lignin.

\section{Hasil dan Pembahasan}

Pulp dibuat dari daun pisang kering dari pohon. Daun pisang yang dipilih adalah daun pisang dengan kualitas baik yang dilihat dari tidak adanya hama yang menempel pada daun. Daun pisang dipilih karena kandungan selulosa dan lignin dalam daun pisang berturut-turut sebesar $44-54 \%$ dan $11-22 \%$ [6]. Syarat bahan yang dapat digunakan sebagai pulp adalah yang mengandung selulosa cukup tinggi sehingga daun pisang dipilih sebagai sumber selulosa. Pembuatan pulp menggunakan prinsip utama yaitu proses delignifikasi. Delignifikasi adalah proses penghilangan kandungan lignin pada bahan berserat menggunakan larutan pemasak tertentu [11, 12]. Sebelum dilakukan proses delignifikasi, daun pisang harus dipotong kecil-kecil terlebih dahulu dengan ukuran yang seragam untuk memperbesar luas permukan bahan dan agar serat dari pulp yang dihasilkan lebih seragam. Daun pisang kering yang digunakan disajikan pada gambar 1.

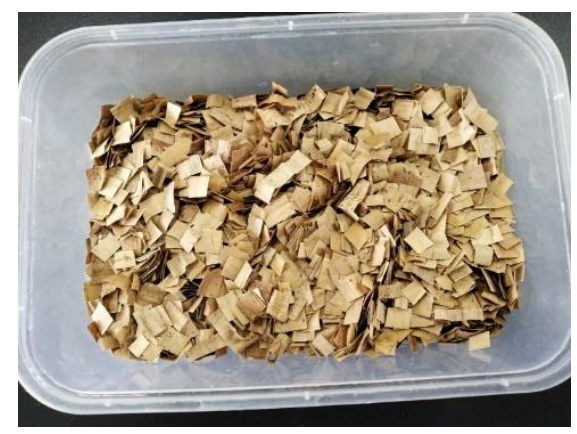

Gambar 1. Daun Pisang Kering sebelum Dilakukan Proses Delignifikasi

Penggunaan larutan pemasak yang berbeda telah digunakan dalam penelitian ini. Larutan pemasak yang digunakan adalah $\mathrm{Na}_{2} \mathrm{CO}_{3}$ dan $\mathrm{NaOH}$. Bahan $\mathrm{Na}_{2} \mathrm{CO}_{3}$ merupakan larutan pemasak dalam pembuatan pulp melalui proses sulfat sedangkan $\mathrm{NaOH}$ merupakan larutan pemasak dalam pembuatan pulp melalui proses soda. Konsentrasi larutan pemasak, waktu reaksi, dan suhu reaksi dibuat sama untuk kedua larutan pemasak. Konsentrasi larutan pemasak yang digunakan sebesar 3\%, waktu reaksi selama 120 menit, pada suhu $105^{\circ} \mathrm{C}$. Konsentrasi larutan pemasak
3\% dan suhu pemanasan 120 menit dipilih sesuai dengan penelitian [7] di mana diperoleh kandungan selulosa dan lignin pada pulp batang pisah dengan baik. Referensi tersebut digunakan dalam penelitian pembuatan pulp dengan daun pisang ini.

Pembuatan pulp dilakukan dengan cara menambahkan larutan pemasak berupa $\mathrm{NaOH}$ $3 \%$ atau $\mathrm{Na}_{2} \mathrm{CO}_{3} 3 \%$. Penambahan larutan pemasak tersebut bertujuan untuk menghidrolisis lignin yang terdapat dalam daun pisang. Saat daun pisang ditambahkan dengan $\mathrm{NaOH}$ akan terbentuk natrium lignat yang dapat larut dalam air dan terpisah dari selulosa [13]. Proses reaksi dilakukan selama 120 menit menggunakan autoklaf. Tujuan digunakannya autoklaf agar suhu reaksi stabil selama proses pemasakan sehingga proses hidrolisis lignin dapat berlangsung secara maksimal. Daun pisang disaring dan dicuci menggunakan etanol. Tujuan pencucian menggunakan etanol untuk melarutkan lignin yang masih terdapat pada daun pisang. Hal ini terbukti dari filtrat yang berwarna coklat hasil dari proses pencucian daun pisang setelah dimasak. Menurut [7], lignin pada tumbuhan merupakan bahan yang tidak berwarna namun jika terkena sinar matahari berubah menjadi kuning hingga kecoklatan. Hal ini mengindikasikan bahwa filtrat hasil penyaringan mengandung lignin yang terlarut dalam pelarut etanol. Didukung oleh [14], lignin dapat larut dalam pelarut organik, dan larutan alkali encer. Proses selanjutnya adalah menambahkan air panas $70{ }^{\circ} \mathrm{C}$ yang bertujuan untuk mencuci dan menetralkan $\mathrm{pH}$ pada daun pisang. Etanol dan air memiliki kemiripan polaritas dimana sama-sama termasuk ke dalam pelarut polar sehingga diharapkan lignin dan zat pengotor lain pada daun pisang dapat larut dan terbawa oleh pelarut sehingga daun pisang terhindar dari zat pengotor yang dapat menurunkan kualitas pulp.

Kualitas pulp dianalisis dengan pengujian rendemen pulp, kadar selulosa, dan kadar air yang didukung analisis interumentasi menggunakan FTIR untuk mengetahui kandungan selulosa secara kualitatif. Rendemen pulp menunjukkan persentase antara berat murni pulp setelah dilakukan proses delignifikasi terhadap berat daun pisang 
[7]. Kadar selulosa menunjukkan persentase banyaknya selulosa murni terhadap jumlah komponen total (selulosa, hemiselulosa, dan lignin) yang terdapat pada pulp. Kadar air menunjukkan berat air murni terhadap berat total pulp. Analisis FTIR menunjukkan grafik pita absorbsi yang menunjukkan keberadaan gugus penyusun selulosa. Hasil kualitas pulp disajikan dalam tabel 1.

Tabel 1. Data Perbandingan Kualitas Pulp dari Larutan Pemasak yang Berbeda

\begin{tabular}{lllll}
\hline Nama Sampel & Jenis Larutan Pemasak & $\begin{array}{l}\text { Rendemen } \\
(\%)\end{array}$ & $\begin{array}{l}\text { Kadar } \\
(\%)\end{array}$ & Selulosa \\
\hline Sampel a & $\mathrm{NaOH} 3 \%$ & 56,5 & 26,07 & 4,96 \\
Sampel b & $\mathrm{Na}_{2} \mathrm{CO}_{3} 3 \%$ & 68,2 & 51,96 & 38,40 \\
\hline
\end{tabular}

Pengaruh Jenis Larutan Pemasak terhadap Rendemen Pulp

Hubungan antara persentase rendemen terhadap jenis larutan pemasak dapat dilihat pada tabel 1. Rendemen pulp yang menggunakan larutan pemasak $\mathrm{Na}_{2} \mathrm{CO}_{3} 3 \%$ (sampel b) lebih besar dibandingkan rendemen pulp yang menggunakan larutan pemasak $\mathrm{NaOH} 3 \%$ (sampel a). Hasil yang diperoleh dari penelitian ini lebih baik dibandingkan industri pulp kimia yang menghasilkan rendemen pada rentang 35\% sampai 63\% [7]. Hal ini menunjukkan bahwa pulp berbahan dasar daun pisang kering dapat digunakan sebagai alternatif pembuatan pulp pada skala industri kimia skala besar. Namun, besarnya rendemen pulp ini tidak bisa digunakan sebagai salah satu penentu bahwa pulp yang dihasilkan memiliki kualitas yang baik. Kualitas pulp dapat ditinjau dari kadar selulosa, kadar air, dan bentuk fisiknya.

Pengaruh Jenis Larutan Pemasak terhadap Kadar Selulosa

Kadar selulosa pada pulp sangatlah penting. Pulp dengan kadar selulosa yang tinggi sangat diharapkan pada industri kertas. Kadar selulosa yang tinggi berkaitan dengan kekuatan tarik yang dimiliki oleh pulp. Pada tabel 1 terlihat bahwa kadar selulosa dari pulp pada sampel $b$ lebih besar dibandingkan kadar selulosa pada sampel a. Hanya sampel b yang memenuhi standar kualitas pulp menurut SNI 7274 yaitu minimal $40 \%$. Kadar selulosa yang rendah pada sampel a dapat dikarenakan konsentrasi $\mathrm{NaOH}$ yang terlalu besar sehingga selulosa pada daun pisang terdegradasi dalam larutan $\mathrm{NaOH}$. Peningkatan kadar $\mathrm{NaOH}$ yang berlebihan berbanding lurus dengan penurunan rendemen yang sebanding dengan penurunan kadar selulosa [13].

Pengaruh Jenis Larutan Pemasak terhadap Kadar Air

Kadar air pada pulp sangat mempengaruhi kualitas pulp. Kadar air yang terlalu tinggi pada pulp dapat mempengaruhi viskositas pulp dan menyebabkan kualitas pulp menurun [15]. Tabel 1 menunjukkan bahwa kadar air pada sampel $b$ lebih besar dibandingkan kadar air pada sampel a. Tingginya kadar air ini juga mempengaruhi rendemen pulp yang didapatkan sehingga sampel $b$ memiliki rendemen yang lebih besar dibandingkan sampel a. Hanya sampel a yang memenuhi standar kualitas pulp menurut SNI 7274 yaitu maksimal 7\%.

Pengaruh Jenis Larutan Pemasak terhadap Tekstur dan Bentuk Fisik Pulp

Pulp dengan warna yang cenderung gelap sangat dihindari karena berpengaruh terhadap fungsi pulp. Pulp dengan warna kecoklatan mengindikasikan bahwa masih terdapat banyak lignin pada pulp. Hal ini mengindikasikan bahwa proses delignifikasi untuk menghidrolisis lignin tidak berjalan maksimal. Pulp yang dihasilkan dari kedua larutan pemasak memiliki tekstur dan bentuk fisik yang berbeda dapat terlihat pada gambar 2. 


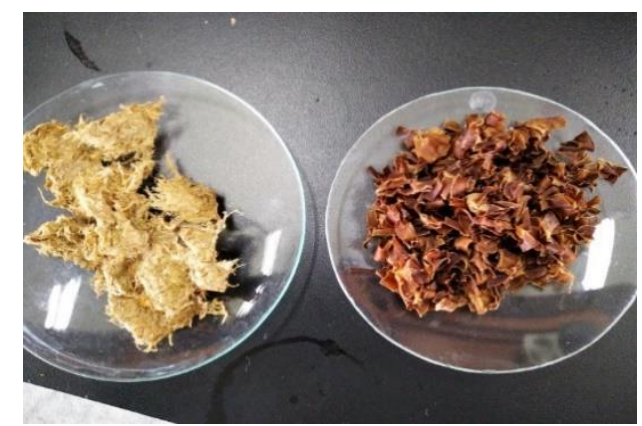

Gambar 2. Tekstur dan Bentuk Fisik Pulp dari sampel a (kiri) dan sampel b(kanan)

Berdasarkan gambar 2, tekstur dari sampel a cenderung halus, berserat, seperti bubur, berwarna kekuningan, memiliki $\mathrm{pH}$ netral sebesar 7 sedangkan sampel $b$ teksturnya masih sama seperti potongan daun pisang sebelum dilakukan proses delignifikasi, serat-serat tidak terlihat, berwarna coklat tua, dan memiliki $\mathrm{pH}$ netral sebesar 7. Bentuk fisik sampel $b$ yang cenderung tidak hancur dan halus mengindikasikan bahwa larutan pemasak $\mathrm{Na}_{2} \mathrm{CO}_{3}$ tidak dapat merusak dinding sel daun pisang sehingga ketika proses pencetakan pulp menjadi lembaran kertas akan lebih sulit. Warna pulp sampel b pada gambar 2(b) cenderung berwarna coklat tua sebagai indikator bahwa kandungan lignin pada kertas masih cukup tinggi. Tingginya kadar lignin dapat menyebabkan kertas menjadi kaku, sulit dibentuk karena lignin bersifat menolak air, dan berwarna kuning yang menyebabkan kualitas pulp rendah [15]. Tingginya lignin juga terlihat dari besarnya rendemen sampel $b$. Semakin tinggi kadar lignin menyebabkan rendemen pulp semakin tinggi karena lignin yang terlarut dalam larutan pemasak semakin rendah yang artinya proses delignifikasi tidak berjalan dengan baik [9].

\section{Analisis dengan FTIR}

Analisis selulosa secara kualitatif dilakukan dengan FTIR untuk mengetahui perbedaan spektra dari daun pisang sebelum dilakukan proses delignifikasi dan setelah proses delignifikasi terhadap jenis larutan pemasak yang berbeda. Hasil spektra dari ketiga sampel dapat terlihat pada gambar 3, gambar 4, dan gambar 5 berikut ini.

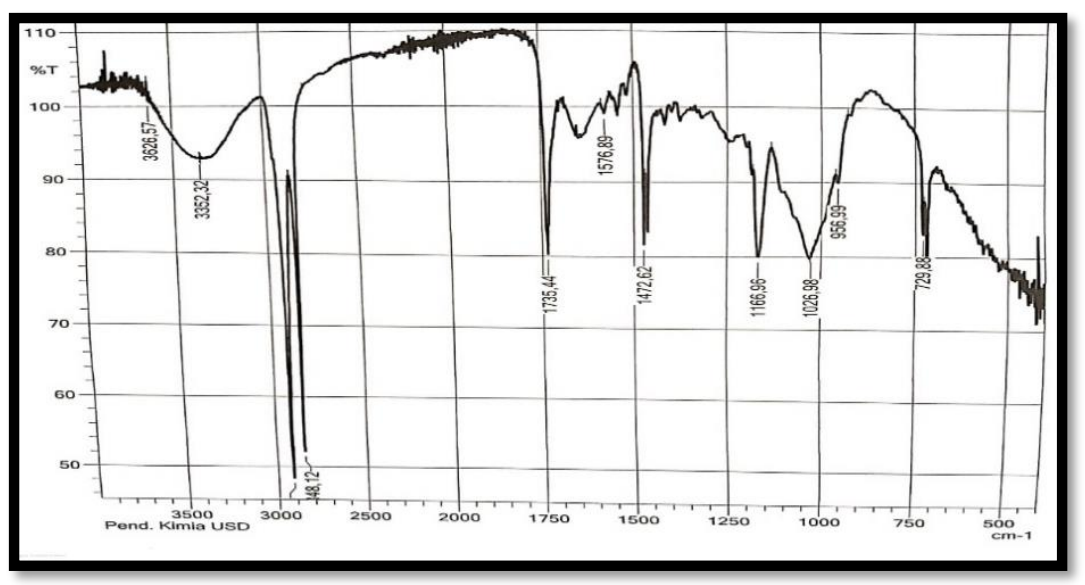

Gambar 3. Hasil Spektra FTIR pada Daun Pisang Sebelum Proses Delignifikasi 


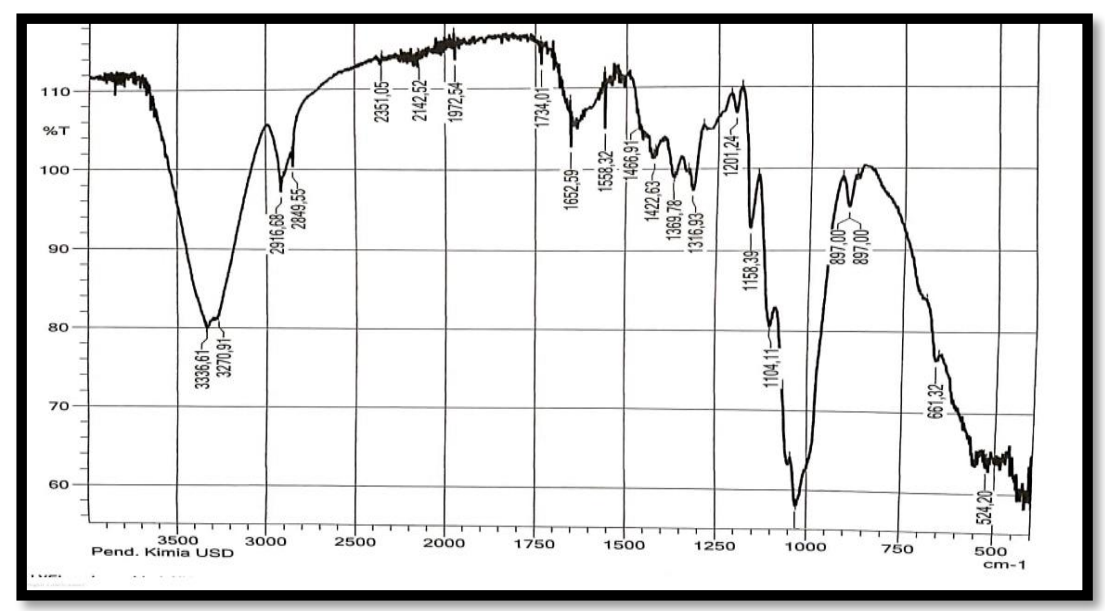

Gambar 4. Hasil Spektra Sampel a

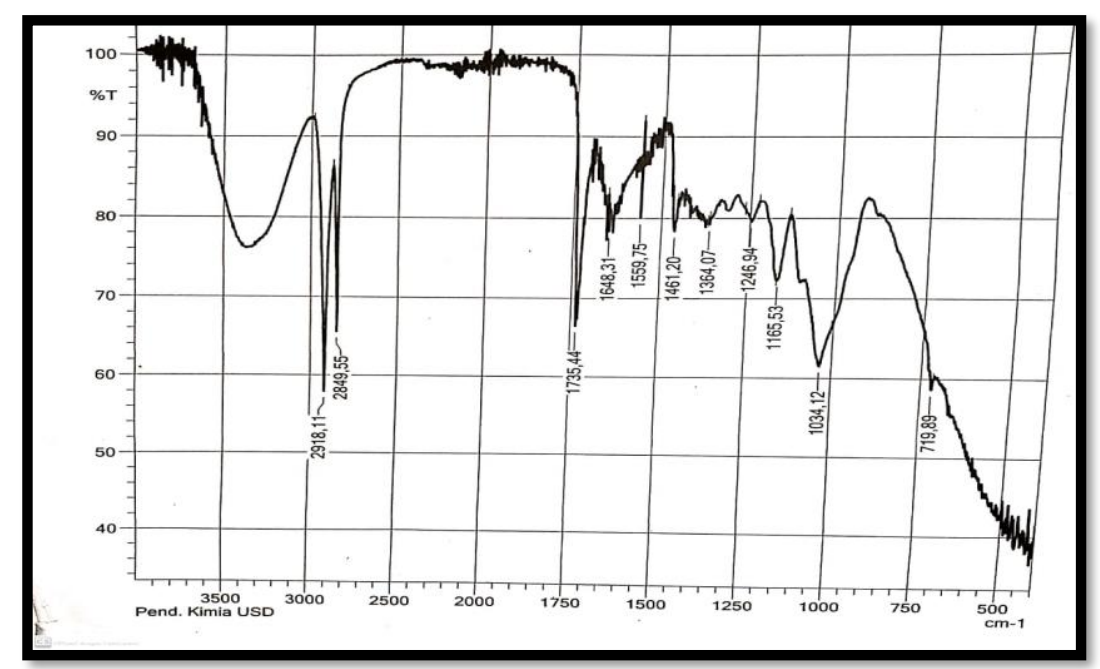

Gambar 5. Hasil Spektra Sampel b

Berdasarkan ketiga spektra dapat terlihat bahwa terdapat absorpsi yang kuat pada daerah serapan $3352.32 \mathrm{~cm}^{-1}, 3336.61 \mathrm{~cm}^{-1}, 3350$ $\mathrm{cm}^{-1}$ pada semua sampel baik yang belum diberi perlakuan delignifikasi maupun yang sudah diberi perlakuan. Absorpsi yang kuat dan luas pada daerah $3355 \mathrm{~cm}^{-1}$ menunjukkan adanya gugus $\mathrm{O}-\mathrm{H}$ peregangan (stretching) pada grup hidroksil selulosa [16]. Pada gambar 3, gambar 4, dan gambar 5 terdapat serapan yang kuat pada $2900 \mathrm{~cm}^{-1}, 2916.68 \mathrm{~cm}^{-1}$, dan $2918.11 \mathrm{~cm}^{-1}$. Hal ini menunjukkan adanya C-H peregangan (stretching) pada $\mathrm{CH}_{2}$ yang terdapat pada grup $\mathrm{CH}_{2} \mathrm{OH}$ selulosa [16]. Dari ketiga sampel baik yang diberi perlakuan maupun yang sudah diberi perlakuan, ketiganya masih mengandung lignin yang terbukti adanya serapan pada daerah 1200 - $1300 \mathrm{~cm}^{-1}$. Pada gambar 3 menunjukkan adanya serapan pada daerah 3336,61 $\mathrm{cm}^{-1}$ yang lebih kuat dibandingkan gambar 4. Hal ini menunjukkan bahwa perlakuan delignifikasi menggunakan alkali $\mathrm{NaOH}$ 3\% dapat mereduksi ikatan hidrogen yang diakibatkan oleh hilangnya gugus hidroksil yang bereaksi dengan $\mathrm{NaOH}$. Besarnya intensitas serapan sebanding dengan besarnya konsentrasi -OH [16]. Dari daerahdaerah serapan yang muncul pada spektra, terbukti bahwa ketiga sampel mengandung selulosa dimana gugus - $\mathrm{OH}$ atau hidroksil selulosa terbanyak terdapat pada perlakuan delignifikasi menggunakan larutan pemasak $\mathrm{NaOH} 3 \%$.

\section{Kesimpulan}

Pembuatan pulp dari daun pisang kering dapat dilakukan menggunakan reaksi delignifikasi menggunakan larutan pemasak $\mathrm{NaOH} 3 \%$ atau $\mathrm{Na}_{2} \mathrm{CO}_{3} 3 \%$. Dari analisis kadar selulosa, kadar air dan instrumen FTIR, pulp 
yang dibuat dengan larutan pemasak $\mathrm{NaOH} 3 \%$ lebih baik daripada $\mathrm{Na}_{2} \mathrm{CO}_{3} 3 \%$ di mana pulp yang dihasilkan memiliki kadar air yang $4,96 \%$, tekstur yang halus dan berserat, warna yang lebih terang, dan menghasilkan pita serapan hidroksil selulosa yang lebih kuat dibandingkan pulp yang dibuat dari $\mathrm{Na}_{2} \mathrm{CO}_{3}$ $3 \%$. Namun, pulp yang dibuat dari larutan $\mathrm{NaOH} 3 \%$ memiliki rendemen (56,5\%) dan kadar selulosa $(26,07 \%)$ yang lebih rendah dibandingkan $\mathrm{Na}_{2} \mathrm{CO}_{3} 3 \%$. Daun pisang kering dapat dijadikan sebagai alternatif dalam pembuatan pulp.

\section{Daftar Pustaka}

1. Rakyat, P., RI Produsen Kertas Nomor 6 Terbesar Dunia, in Pikiran Rakyat 2016.

2. Małachowska, E., et al., Analysis of Cellulose Pulp Characteristics and Processing Parameters for Efficient Paper Production. Sustainability, 2020. 12(17): p. 7219.

3. Mohieldin, S.D., Pretreatment Approaches in Non-wood Plants for Pulp and Paper Production: A Review. Journal Of Forest Products \& Industries, 2014. 3(2): p. 84-88.

4. Adi, D.S.; Wahyuni, I.; Risanto, L.; Rulliaty, S.; Hermiati, E.; Dwianto, W; Watanabe, T., Central Kalimantan's Fast Growing Species: Suitability For Pulp And Paper. Indonesian Journal of Forestry Research, 2015. 2(1): p. 21-29.

5. Reddy, N.; Y. Yang, Fibers from Banana Pseudo-Stems. 2015, Berlin: Springer.

6. Das, S.; Rahman,;Hasan, M., PhysicoMechanical Properties of Pineapple Leaf and Banana Fiber Reinforced Hybrid Polypropylene Composites: Effect of Fiber Ratio and Sodium Hydroxide Treatment. IOP Conference Series: Materials Science and Engineering, 2018. 438: p. 012027.

7. Bahri, S., Pembuatan Pulp dari Batang Pisang. Jurnal Teknologi Kimia Unimal 2015. 4(2): p. 36-50.

8. Saleh, A.; Pakpahan, M.M; Angelina, N, Pengaruh Konsentrasi Pelarut, Temperatur dan Waktu Pemasakan Pada Pembuatan Pulp dari Sabut Kelapa Muda. Jurnal Teknik Kimia, 2009. 3(16): p. 35-44.

9. Andaka, G. ; D. Wijayanto. Pemanfaatan Limbah Ampas Tebu untuk Memproduksi Pulp dengan Proses Soda. in Prosiding Nasional Rekayasa Teknologi Industri dan Informasi XIV. 2019. Yogyakarta: Sekolah Tinggi Teknologi Nasional (STTNAS).

10. Dewi, T.K.; Wulandari, A.; Rony, Pengaruh Temperatur, Lama Pemasakan, dan Konsentrasi Etanol pada Pembuatan Pulp Berbahan Baku Jerami Padi dengan Larutan Pemasak $\mathrm{NaOH}$ Etanol. Jurnal Teknik Kimia 2009. 3(16): p. 11-
20.

11. Jablonsky, M.; Majova, V.; Skulcova, A.; Haz, A., Delignification of pulp using deep eutectic solvents. J Hyg Eng. 2018. 76-81.

12. Smink, D.; Kersten, S.R.A. ; Schuur, B., Process development for biomass delignification using deep eutectic solvents. Conceptual design supported by experiments. Chemical Engineering Research and Design, 2020. 164: p. 86-101.

13. Suryani, Pembuatan Pulp dari Daun Pisang. Jurnal Photon, 2010. 1(1): p. 31-36.

14. Asip, F.; Wibowo, Y.P.; Wahyudi, R.T. Pengaruh Basa terhadap Penurunan Lignin dan Konsentrasi HCl pada Hidrolisa Sabut Kelapa untuk Memproduksi Bioetanol. Jurnal Teknik Kimia, 2016. 22(1): p. 10-20.

15. Fariati, I.; Pengaruh Konsentrasi Larutan Pemasak dan Lama Pemasakan pada Proses Delignifikasi Campuran Pelepah Pisang dan Tanda Kosong Kelapa Sawit untuk Pembuatan Pulp, in Jurusan Kimia. 2016, UIN Alaudin Makasar: Makassar.

16. Aditama, A.G.; Farid, M.; H. Ardhyananta, Isolasi Selulosa dari Serat Tandan Kosong Kelapa Sawit untuk Nano Filler Komposit Absorpsi Suara: Analisis FTIR. Jurnal Teknik ITS, 2017. 6(2): p. 228-231.

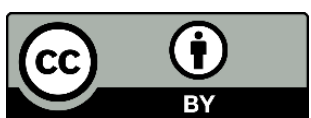

(C) 2021 by the authors. Licensee Fullerene Journal Of Chem. This article is an open access article distributed under the terms and conditions of the Creative Commons Attribution (CC BY) license

(http://creativecommons.org/licenses/by/4.0/). 